\title{
ЗАЯВЛЕНИЕ РАБОТНИКА О БАНКРОТСТВЕ КАК ВОЗМОЖНОСТЬ ИНИЦИИРОВАТЬ ПОДКОНТРОЛЬНУЮ ПРОЦЕДУРУ БАНКРОТСТВА
}

\section{AN EMPLOYEE'S STATEMENT \\ FOR BANKRUPTCY AS A POSSIBILITY \\ TO INITIATE A SUPERVISED BANKRUPTCY PROCEDURE}

\section{S. Sukhanov}

Summary. This article is devoted to issues of abuse of the right by creditors at the stage of initiating a bankruptcy case. The article proposes to exclude the right of employees, former employees to apply to the court with a petition for declaring the debtor bankrupt.

Keywords: debtor, competitive creditors, bankruptcy, insolvency, monetary obligation, abuse of right.

\author{
Суханов Сергей Вячеславович \\ Аспирант, ФБГОУ ВО «Российский государственный \\ университет правосудия» \\ sergeysworking@gmail.com
}

Аннотация. Данная статья посвящена вопросам злоупотребления правом кредиторами на стадии возбуждения дела о банкротстве. В статье предлагается исключить право работников и бывших работников обращаться в суд с заявлением о признании должника банкротом.

Ключевые слова: должник, конкурсные кредиторы, банкротство, несостоятельность, денежное обязательство, злоупотребление правом.

датель формально не относит к денежным (хотя очевидно, что с точки зрения содержания данные требования таковыми, несомненно, являются).

В силу отсутствия статуса конкурсных кредиторов работники и бывшие работники по-прежнему не вправе принимать участие в собрании кредиторов с правом голоса. Между тем, в Закон о банкротстве была введена статья 12.1, регулирующая порядок проведения арбитражным управляющим собрания работников и бывших работников должника и избрание представителя работников должника для целей участия в собрании кредиторов, в соответствии со статьей 12 Закона о банкротстве.

В случае включения в реестр требований кредиторов только требований о выплате выходных пособий и (или) об оплате труда лиц, работающих или работавших по трудовому договору, и неудовлетворения указанных требований первое собрание кредиторов не проводится, и арбитражный суд принимает решение о введении процедуры, применяемой в деле о банкротстве, в соответствии с абзацем 2 пункта 2 статьи 75 Закона о банкротстве (как в случае, если первым собранием кредиторов не принято решение о применении одной из процедур, применяемых в деле о банкротстве).

Следует также отметить, что наделение работников правом на обращение с заявлением о признании должника банкротом, не в полной мере может способствовать защите интересов работников. 
Как написано в пояснительной записке к законопроекту [3], данные изменения вносились в целях повышения эффективности защиты права работников на получение заработной платы и стимулирования недобросовестных работодателей к своевременной выплате заработной платы под риском банкротства, однако, порядок подтверждения данной задолженности судебным актом не претерпел изменений.

Возможность работника получить причитающуюся ему заработную плату и связанные с трудовой деятельность выплаты при самостоятельном инициировании банкротства никак не выше чем в случае, когда банкротство инициируется конкурсными кредиторами.

Складывается ситуация, при которой говорить о своевременной выплате заработной платаны под риском банкротства не совсем уместно, т.к. право на инициирование процедуры банкротства никоим образом не ускоряет реальное получение работником заработной платы в связи с тем, что процедура банкротства длится достаточно продолжительное время.

Наделение работников, бывших работников возможностью обращаться в суд с заявлением о признании должника банкротом излишне.

Институты защиты прав работников и так достаточно развиты, например, судебный приказ, трудовые инспекции, а также деятельность органов прокуратуры. Работники могут пожаловаться в Прокуратуру и Трудовую инспекцию, подать заявление о привлечении руководства работодателя к административной (ст. 5.27 КоАП РФ), уголовной (ст. 145.1 УК РФ) и дисциплинарной ответственности (ст. 192 ТК РФ). Это куда более опасный риск для руководителей предприятия, нежели риск наступления несостоятельности их организации.

Деятельность судебных приставов-исполнителей также является очень эффективной. Приставы-исполнители наделены широкими полномочиями, прибегнув к которым более реалистично получить своевременное удовлетворение работниками своих требований, нежели, через банкротство.

Работник может и не обращаться в службу судебных приставов, а самостоятельно обратиться в кредитную организацию, в которой у работодателя открыт расчетный счет. Работнику с большой долей вероятности будет известно, в каком банке открыт счет, наверняка с такого счета он, когда-либо получал заработную плату.

Из приведенных доводов видно, что работник, бывший работник способен получить причитающиеся ему де- нежные средства и не прибегая к банкротству своего работодателя. Более того, данные методы намного быстрее и оперативнее, в отличии от процедуры банкротства.

Как и до внесения поправок в Закон о банкротстве работники были наделены преимущественным правом на удовлетворение своих требований.

Видится достаточно опасным возможность одного работника признать организацию банкротом, так как экономическая деятельность сопряжена с рисками и не исключены сезонные, временные трудности в деятельности предприятия, возможно, экономическая ситуация в определенный промежуток времени может стать затруднительной, но к примеру, в скором бедующем, с применением эффективного управления его финансами и производством, правильным определением стратегических целей и тактик, предвидится поступление денежных средств от контрагентов за выполнение очередного заказа, заключение прибыльного контракта и т.п.

Задолженность по заработной плате и причитающимся выплатам может и не оспариваться работодателем, но требовать определенного временного промежутка, в целях наполнения фонда оплаты труда, для погашения образовавшейся задолженности, а выдача судебного приказа очень скоротечна, и должным образом отреагировать на сложившуюся ситуацию у работодателя просто не будет времени, да и возможности, так как судебный приказ выносится без судебного заседания и без вызова сторон (ст. 126 ГПК РФ), в отличие же от споров с контрагентами, с обязательным претензионным порядком и достаточно длительным судебным разбирательством.

Но в настоящее время практика применения данной нормы, дающая возможность работникам быть заявителями в деле о банкротстве, показывает, что она в большей мере стала инструментом недобросовестных владельцев предприятий, для достижения целей инициирования подконтрольной процедуры банкротства (См. например: Дело № А19-2163/2016; Дело № А19-2164/2016; Дело № 19-11332/2016; Дело № А1911314/2016 (все должники в указанных делах входили в одну группу лиц, система инициирования банкротства для всех была одинаковой, а именно заявителями выступали работники данных предприятий). [4, 5, 6, 7]. Так как при обращении с заявлением должника, у самого должника отсутствует право указать кандидатуру арбитражного управляющего, а также саморегулируемую организацию арбитражных управляющих из числа, которых представляется выбрать последнего (п. 5 ст. 37 Закона о банкротстве). Создание искусственной задолженности с контрагентом проблематично и требует значительных временных и технических затрат, для того 
чтобы этот подконтрольный кредитор обратился с заявлением о признании должника банкротом, в котором указана угодная кандидатура арбитражного управляющего. С работником же гораздо все проще: начисляется искусственно созданная задолженность за три месяца и в размере достаточном для инициирования банкротства (начисление премий, переработки в нерабочее время и т.п.), затем, на основании данной задолженности, работник получает судебный приказ в течение пяти дней, после подается заявление о признании должника банкротом вместе с ходатайством о принятии мер по обеспечению заявления и вот, в течение шести дней, инициирована процедура банкротства.

На основании сделанных выводов, видится целесообразным пересмотреть возможность работников инициировать процедуру банкротства.

На взгляд автора данной статьи, сложившаяся практика применения данной нормы не отвечает тем целям и задачам, которые перед ней ставил законодатель, а наоборот дает возможность возбуждения подконтрольной процедуры банкротства недобросовестными владельцами предприятий.

На основании изложенного, предлагается исключить право работников инициировать производство по делу о банкротстве.

Исключение данного права работников, не ограничит реальное и своевременное взыскание заработной платы и причитающихся выплат, так как институты защиты прав работников и так достаточно развиты, они более мобильны и оперативны. Даже в самой процедуре банкротства работники имеют преимущественное право на удовлетворение своей задолженности. Исключение права инициировать процедуру банкротства, наоборот, позволит пресечь возможность недобросовестных владельцев предприятий инициировать подконтрольную процедуру банкротства.

\section{ЛИТЕРАТУРА}

1. Федеральный закон от 26.10.2002 № 127-Ф3 «0 несостоятельности (банкротстве)» // 28.10.2002, N43, ст. 4190;

2. Федеральный закон от 29.06.2015 № 186-Ф3 «0 внесении изменений в отдельные законодательные акты Российской Федерации» // СЗ РФ. 06.07 .2015$. № 27. ст. 3977;

3. Система обеспечения законодательной деятельности Государственной автоматизированной системы «Законотворчество» (СОзД ГАС «Законотворчество»). [Электронный ресурс] // URL: http://sozd.parlament.gov.ru/bill/316848-6 (дата обращения: 02.12.2019);

4. артотека арбитражных дел Дело № A19-2163/2016 [Электронный ресурc] // URL: http://kad.arbitr.ru/Card/3b87de80-9a79-47cb-906b-ff68f552b9a3 (дата обращения: 02.12.2019);

5. Картотека арбитражных дел Дело № A19-2164/2016 [Электронный ресурс] // URL: http://kad.arbitr.ru/Card/0c1660d4-a1fb-4f9b-879a-6d8b9d23a4a5 (дата обращения: 02.12.2019);

6. Картотека арбитражных дел Дело № A19-11332/2016 [Электронный ресурс] // URL: http://kad.arbitr.ru/Card/7fd2b759-cdb6-49f7-883c-efbc8d5934af (дата обращения: 02.12.2019);

7. Картотека арбитражных дел Дело № A19-11314/2016 [Электронный ресурс] // URL: http://kad.arbitr.ru/Card/188618a0-ca86-4470-a92e-eee8365a7b75 (дата обращения: 02.12.2019)

(c) Суханов Сергей Вячеславович ( sergeysworking@gmail.com ). Журнал «Современная наука: актуальные проблемы теории и практики» 